Meta

Journal des tradlucteurs

Translators' Journal

\title{
Literary Translation in Africa: The Nigerian Experience
}

\section{Jide Timothy Asobele}

Volume 34, numéro 4, décembre 1989

URI : https://id.erudit.org/iderudit/001911ar

DOI : https://doi.org/10.7202/001911ar

Aller au sommaire du numéro

Éditeur(s)

Les Presses de l'Université de Montréal

ISSN

0026-0452 (imprimé)

1492-1421 (numérique)

Découvrir la revue

Citer cet article

Asobele, J. T. (1989). Literary Translation in Africa: The Nigerian Experience. Meta, 34(4), 686-702. https://doi.org/10.7202/001911ar d'utilisation que vous pouvez consulter en ligne.

https://apropos.erudit.org/fr/usagers/politique-dutilisation/ 


\title{
LITERARY TRANSLATION IN AFRICA: THE NIGERIAN EXPERIENCE
}

\author{
JiDE TIMOTHY ASOBELE \\ University of Lagos, Lagos, Nigeria
}

\section{PREAMBLE}

When we remember the reckless abandon with which Germans, French, English, Portuguese, and Belgians (European powers) partitioned Africa in Berlin in 1884, in what is generally called the scramble for Africa and the speed with which they gave the partition military, customs, and cultural reality, we of this generation should try our hands at storming the vestiges of these military, customs and cultural barriers. It is true, as Asiwaju (1984: 10) has pointed out that:

One terrible effect of colonial partition on Africans has been the establishment of different colonial educational systems and the introduction of official language barriers and a general cultural alienation of the Western-educated Africans one from another even in areas along state boundaries where the educated elites on both sides have the shared background of a common African culture.

Three illustrous Africans: one, a traditional rule, the Alaketu King of Ketu; another, Hubert Ogunde, a world renowned playwright and dramatist and, finally, a modern-time statesman, Dr. Emil Derlin Zinsou, a former president of Dahomey (1968-1969) have influenced our resolve to write this article.

The Alaketu of Ketu, King of Ketu, the renowned ancient Yoruba city in the present-day Republic of Benin (formerly Dahomey) was reported by Asiwaju (1984: 9) as saying:

We regard the boundary as separating the English and the French not the Yoruba.

For his part, Hubert Ogunde carried his cultural evangelical messages in drama form to his kith and kin in the Republics of Benin, Togo, Ghana, etc., as if English and French languages did not exist in these former English and French possessions. And Dr. Emil Derlin Zinsou, bent on putting his views across to reporters who understood only English, at Ikeja Airport, addressed the journalists in Yoruba language.

With this singular action of his, Dr. Zinsou removed the artificial barriers built with a blue pencil by the partitioning Europeans (France and Britain) a hundred years ago. This was a symbolic action, very akin to the mental state of mind of the Alaketu of Ketu.

That there are Ivorian, Beninois, Nigerian, Ghanaian version of the Tales of the Turtle and the Hare, the myth of Moremi, the escapade of Anansa the spider, attests to the fact that pre-colonial Africans kept the linguistic and cultural link alive. To this may be added the fact that the Yoruba of the diaspora in Cuba, Brazil and Tobago still keep alive this fund of African literary patrimony. A fact that becomes evident in the title of the translated work of Cuban Lydia Cabrera: Pourquoi: Nouveaux contes nègres de Cuba, translated from Spanish to French by Francis Miomandra and published in Paris in 1954 by Gallimard. Nicolas Guillen, the Cuban poet, attested to the robust nature of the language and art of the Yorubas in Cuba, in spite of the Spanish language, in his poem "Son 
Numero 5" published with a double title in Spanish and English: Patria O Muerte! The Zoo and Other Poems, translated by Robert Marquez and published in Havana by Editorial Arte y Literatura in 1975. The problems of borderlands or of artificial boundaries are essentially human.

Stemming these cultural and linguistic barriers is therefore our aim in this article. Cynics might ask why, of all the development problems, political, economic, environmental, etc., plaguing Africa today, we should focus on translation as central to the overall development of Africa? Translation in a good language is important. Because according to Confucius as quoted by Timothy Asobele (1984: 39):

If language is not correct, then what is said is not what is meant, if what is said is not what is meant, then what ought to be done remains undone; if this remains undone, morals and arts deteriorate; if morals and arts deteriorate justice will go astray; if justice goes astray, the people will stand about in helpless confusion. Hence there must be no arbitrariness in what is said. This matters above everything.

This quotation is important to our subject because of the light it sheds on the need to correct language not only in China, but in Africa, where resolution after resolution has not helped the people to come to grips with their cultural realities and language problems. Since literary translations will help people of diverse cultural backgrounds to have an additional cultural luggage to theirs, and since translations aid interpreting and communication and since communication uses language medium and since one can best mobilise people if one speaks in the language they understand, herein lies the importance of literary translation in Africa.

In this article, therefore, we shall look at:

Why literary translations in Africa?

Problems of literary adaptation and translation: the case of Lanke Omu (The Drinkard) by Kola Ogunmola.

Literary translations: publishers, African Universities and critics, etc.

\section{WHY LITERARY TRANSLATION IN AFRICA?}

1.0 In conference after conference, before and after African States' independence, to wit: at the Second Congress of Negro Writers and Artists in Rome, 1959; at the UNESCO conference on the influence of colonialism on culture in Dar es Salaam, 1971; at African Ministers of Culture Conference on cultural policies in Accra, October, 1975, there were clamours for the adoption of a continental language, to be chosen from the authentic languages of the African peoples in use upon the continent. And precisely in Freetown 1963, there was that famous resolution that African literary patrimonies should be taught in our schools, colleges, and universities. Why all these clamours for both cultural and language policy for the continent, if not to bridge the communication gap among all the peoples of Africa?

Today we are aware of the fact that Nigerian primary school children read The African Child by Camara Laye from the Republic of Guinea; God's Bits of Woods by Sembene Ousmane, Mission to Kala by Mongo Beti, Houseboy by Ferdinand Oyono, The Ambiguous Adventures by Cheik Hamodou Kane, etc., in translation. (For a list of translated works from French to English and English to French see Appendices IV-V.)

The question is why should African teachers teach African material to a culturally colonised people? Professor Michael J.C. Echeruo (1981: 363) exclaimed, in his paper "Concert and Theatre in Late 19th Century Lagos", published in Yemy Ogunbiyi's edited work Drama and Theatre in Nigeria: A Critical Source Book: 
That a country should rise with a literature entirely foreign almost assumes to me the form of an impossibility because, after all, the legend of Troy, it must be admitted for interest, stands pre-eminent; but what can equal for beauty and poetical embellishments the legends of IleIfe, that cradle of mankind as tradition relates. Their oratical powers have immortalised the name of Demosthenes and Cicero but their orations in many points cannot be said to excel those that have been delivered in the house of Ogboni at Abeokuta or those in the palace of Alaafin of Oyo (as depicted in Oba Koso), or those that have moved the soldiery to deeds of bravery in the camp of field-marshal Ogedengbe of Ilesha? If the world had got only the English translation of the Iliad and Greek of the Paradise Lost, or if the English edition of Divine Comedy were all that is available, what little lustre would they have shed on the genius of Homer or Milton and of Dante! It is in their native language that they severally gained an immortal wreath for themselves in the world of literature; and it is those more than any other that they ought. It becomes us then as those seeking the good of their country to deprecate most vigorously a habit of boasting with borrowed plumes. Otherwise the fate of the Jack-daw in the Fables of Phaedrus would soon be ours.

It is gratifying to add that the poetics and the powerful dramatic exposition and excellence that Oba Koso, Obaluaye, Langbodo, Eda and Omuti, all Yoruba plays, display are responsible for our French versions of the same titles, for example. After all our Sango of Oba Koso is a powerful monarch who has his equal only in Shakespearian, Cornellian, and Racinian tragic heroes. It is to share our literary patrimonies with our Francophone brothers that we decide to translate these masterpieces into French language. We are aware of Senghor's literary adaptation, not to say translation, of Thomas Mofolo's Chaka, itself written in Tsetsewa before Mofolo translated it into English. The question then is: Why has a Senegalese not chosen Lat Dior or Samory Toure for his literary creation? We can conjecture that Senghor, an apostle of dialogue of cultures, saw in his adaptation a way of pressing home his avowed ideal of stressing intergroup cooperation.

Senghor also could be said to have wanted to give pride of place to an African historical figure, like Chaka, in a preindependence era. For not too long ago primary pupils in a section of Africa were forced to recite the colonial creed of "our ancestors the Gauls". This form of creed smacks of historical "double-think", if only we remember that the military exploits of some African historical figures equalled if not surpassed those of Napoleon, Alexander the Great, etc.

A fact that shows that translations of African works from, say, Yoruba to French, English to French, Yoruba to Portuguese, etc., will go a long way in disseminating Africans' national patrimonies, not only to Yoruba, Hausa, Swahili speaking peoples, etc., but also to Francophone, Lusophone, Hispanophone peoples of the world. This way literature will help project the African world view. After all, books are cultural commodities. And theatre is a lieu of mass-communication. And that is why we are examining some Yoruba plays translated into English and French. These translations in diverse tongues and languages will aid the renommée of the different African writers. Translations can also help develop the reputation of an African author. Take, for instance, the poetry prize of the 1966 Dakar Negro African Festival that went to Congolese Tchicaya Utamsi's collection entitled Epitomé. But the question is: How did the heterogeneous members of the jury who could perhaps speak only English, French, Portuguese, Spanish, Swahili, etc., come to the conclusion that it was Tchicaya and not J.P. Clark, Christopher Okigbo, Wole Soyinka that should be given such an honour?

How does a French-speaking member of the jury realise the beautiful use of transliteration by Okigbo while he is not steeped in Igbo culture? And even if they had a French translation on hand, it is true that each culture has its own way of looking at the general world, and since culture and language are intimately related, problems are bound to arise 
when attempts are made to articulate one culture in the language of another. This is not to say that translations are not useful. They are. We know that Homer's Iliad and Odyssey influenced Racine's Iphigénie and Andromaque, these two works are masterpieces of the genre in their own right. We may add yet another example where literary movements influenced the writing of other countries. We are aware of the influence of J.-J. Rousseau's Romanticism on the following English poets: William Blake, William Wordsworth, S.T. Coleridge and John Keats. The influence of Balzac's Rastignac on Dostoevsky gave birth to Raskonikov, the superman. Senghor certainly has influenced the writings of such Camerounians as R.P. Englebert Mveng and Prof. Eno-Belinga, just to mention a few. Intra-African and inter-African communication problems will be reduced to a manageable level if this cultural exchange through literary translations is encouraged by African States. This is because literary translation will aid the spread of knowledge about other African countries' cultural values and make civilization contact easier. It will also smash the artificial linguistic barriers all over Africa. It is now a cultural fact that the Yoruba world view is universally known, thanks to the works of translators and interpreters like Pierre Verger, Leo Frobenius, Bascom, Janheinz Jahn, etc., who have written on the enduring nature of Yoruba language, poetry, and culture in Cuba, Brazil, and on the metropolitan Yoruba of Benin and Nigeria.

\subsection{Problems of literary adaptation and translation.}

The case of Lanke Omu (The Drinkard) by Kola Ogunmola.

In this section we shall write on the problems Val Olayemi encountered while trying to translate Lanke Omu into English and the problems this writer encountered while translating same into French. As Val Olayemi noted (1968: 29):

The non-correspondence of Yoruba and foreign idiom presents great problems to the translator of Yoruba verse. With a language drawing its imagery chiefly from the culture and the traditions of the people, it is difficult to be faithful to the original and even more difficult not to dull its verbal brilliance in translation. Moreover, much of the language of Yoruba poetry is closely-knit, and it requires more than ordinary efforts to do full justice to it in translation. The perspiring translator, anxious to keep to the letter of the original, is all too apt to lose himself in a labyrinth of ideas.

The duty of the translator is that of a copycat. This means he must not consider himself as an artist on a stage who can interpret a character's role with personal initiatives. The translator cannot take liberties with the work of another person. His role is to remain as close as he can to the meaning of the original work. His loyalty therefore is to the poet, not to himself. But it must be said here that one does not have to be a poet to be able to translate the poetic work of Kola Ogunmola. But as Val Olayemi stated (1968: 29):

All that a translator of poetry really needs is a sound knowledge of the original language, a good style in the language of the translation, some skill in versifying and a certain sensitivity to words.

It is important to note the injunction of Mr. Val Olayemi here. He feels it is hardly desirable that a poet should translate the work of another poet, because:

When a poet sees flaws in the poetry of another, the likelihood is that he will make up for these flaws in his translation.

Linguistic affinity between source language and target language does not necessarily remove difficulties in literary translation. Significantly enough, Yoruba and the languages 
into which Lanke Omu is being translated, namely English and French, are worlds apart. Val Olayemi (1968: 29), desirous to make his point, enumerated what he considers to be certain specificities of Yoruba verse generally:

Lines of Yoruba verse are generally short. Paradoxically therein lies the germ of one of the greatest problems of translation. Some of the lines are epigrammatic in character, while many others are the product of intense word contractions and compressed thoughts. A statement may have two or three levels of meaning and, sometimes, spelling out a single line of the original may take many words, enough to form two or more separate lines (...)

Even a one-word line may not be easy to dispose of, as we find in the market scene in Lanke Omu (The Palmwine Drinkard):

Iyaanre!

(Here is) good pounded yam!

The English rendering of "Iyaanre!" is certainly not adequate for Yorubaphone English speakers. This is because of the fact that he knows that "Iyaanre!" is the Yoruba way of offering iyaan for sale. He therefore knows that we need to add more words to give this impression. But the pertinent question is: Does the Englishman understand the cultural meaning that goes with the translation? Certainly not.

Line for line rendering of Yoruba verse was suggested by Val Olayemi, but we feel that such a translation will be too literal and lead to absurdities. The use of footnotes is too distracting and may not be useful after all in the staged version of a poetic work like Lanke Oтu. This is because of the fact that such addenda will spoil the poetic interpretation or reading of the work. One of the translator's major problems therefore is how to keep the line of the target piece as short as that of the original. This is because of the fact that if the line of translation is too long, it loses the pungency of the original and there is where the translator may have to fall back on his inventiveness.

All poetry harnesses the resources of sound to those of the sense, and Yoruba poetry is no exception. A careful translator pays attention therefore to the interplay of sound and sense in Yoruba verse. Let us quote The Palmwine Drunkard or Lanke Omu to buttress this point. According to Val Olayemi (1968: 32):

At the end of a long speech in the The Palmwine Drunkard, the Female spirit says Owara Ojo a ro. Two words here, Owara and ro, are phonaesthetic and the whole sentence is prophetic in tone. In such a line the translation must try to recapture something of the auditory beauty of the original, giving us a line such as squally showers will fall!

The danger in literary translation is that the translator can easily slip into a hack attitude, a situation that can degenerate into the use of clichés or resorting to the nearest expressions he can find. Such expressions may sound impressive but may not be necessarily appropriate. This is a dangerous situation for the dialogue of culture that literary translations promote. The translator must remember that he is transmitting the thoughts of great minds and the world view of the people whose literary patrimony he sets out to translate. He is the link between the two languages. His job is therefore to aid others to participate in the life of others. He must preserve in his translation the culture of the people whom he is the interpreter. It is important for him to realise that each line or stanza is an expression of the social life of the people. That is why Lanke Sobriquet becomes culturally significant "Father of Gods-who-could-do-everything-in-this world". This needs to be hyphenated in the English version. The problem with the original version of Lanke Omu is the total absence or say the chaotic state of punctuation. This type of romantic, not to say revolutionary verse may be due to the difficulty of preserving in black and white a work that is essentially oral. Lanke Omu, an opera, is best enjoyed in 
performance than in its published form. After all, there can be no final version or translation of a truly great poet. André Gide had tried his hand on Shakespeare's works at the beginning of this century, so has Prof. Henri Evans. This leads us naturally to the French version of Lanke Omu and the problems encountered by this writer.

It is important that we disclose the historical fact that the first Nigerian work to be translated into French is The Palmwine Drinkard and his Dead Palmwine Tapster in the Dead's Town by Amos Tutuola. In 1953, a year after its publication by Faber and Faber of London, Raymond Queneau, a French writer, translated it into French with the title: l'Ivrogne dans la brousse. Raymond Queneau (1953: 7) wrote about the translation problems he encountered in these terms:

La traduction présentait quelques problèmes particuliers. L'auteur, par exemple, utilise les conjonctions de la langue anglaise (notamment but et or) d'une façon inhabituelle qui m'a donné bien du souci. D'autre part, $j$ 'ai dâ résister à la tentation de rationaliser un récit dont les «inconséquences» et les «contradictions» se glissent parfois dans la structure même des phrases ${ }^{1}$.

The word "tapster" for example, which was a pure fabrication of the Nigerian writer Amos Tutuola, gave Queneau problems, for according to him:

Un palmwine tapster est un «tireur de vin de palme». J'ai traduit cette expression par «malafoutier», bien que ce mot soit employé au Congo et non en Afrique occidentale. "Grisgris» est pour juju et "féticheur» pour juju-man 2 .

The point is that since 1953, this work has not ceased to inspire writers, translators, readers, dramatists, students, teachers, who still devote long essays, memoirs, articles, theses, critical works on the work of this enchanting writer. This is one of the reasons for the theatrical adaptation in 1962 of the same work by the late Nigerian dramatist Kola Ogunmola, under the auspices of the Department of Theatre Arts of the University of Ibadan and the Institute of African Studies of the same university. This adaptation into Yoruba language was an immediate success on the Ibadan campus. The same Yoruba adaptation toured Nigeria and Ghana in 1963 and 1967. To crown the theatrical success of this Yoruba adaptation, the jury of the theatrical committee of the 1969 Pan-African Festival of Algiers awarded it the second prize.

The catalogues of successive honours received by this play spurred us to translate the work into French in 1982, just as Val Olayemi and Armstrong did for the same work in 1968 (reference to the first section of this article).

Omuti is a Yoruba opera sung with the accompaniment of the Yoruba Bata ${ }^{3}$ drums. There is therefore a fundamental difference between the work of Amos Tutuola and the Yoruba adaptation by Kola Ogunmola. Omuti is structurally musical - a characteristic of Yoruba poetry, while the work of Amos Tutuola is in prose, hence its novel form. This theatrical adaptation by Kola Ogunmola is poetic and dramatic. But it must be said here that Ogunmola's work is first of all an adaptation and a translation in good Yoruba, qualities that helped Val Olayemi in his English translation of the same work.

In his adaptation and translation, Ogunmola recreated characters. He has introduced some real characters with names: Lanke for the drinkard and Bisi for his wife, while Ayo, Jide, Dada, Ropo, Gbade are names of all the drinkard's friends. Alaba is the name of the tapster. In Tutuola's work the names of the drinkard and his wife were not given. Only the name of their child, Zunjir, was given.

In the French translation we had difficulty in establishing some equivalents between Yoruba and French languages. This is because of the fundamental differences between Yoruba and French language and grammar. Differences that are manifested in 
linguistic habits of Yoruba utterances such as: proverbs, riddles, the esoteric language, of the spirit world or of cults and secret societies; the drum language of the poetic Bata Drums; non-verbal languages like the colour of costumes, white for Obatala adepts, red for Sango worshippers, body language, facial scarifications that carry meanings and give clues to character portrayal or depiction. An Oyo on a staged dramatisation of, say, a play like Oba-Koso by Duro Ladipo is supposed to have the following facial scarification:

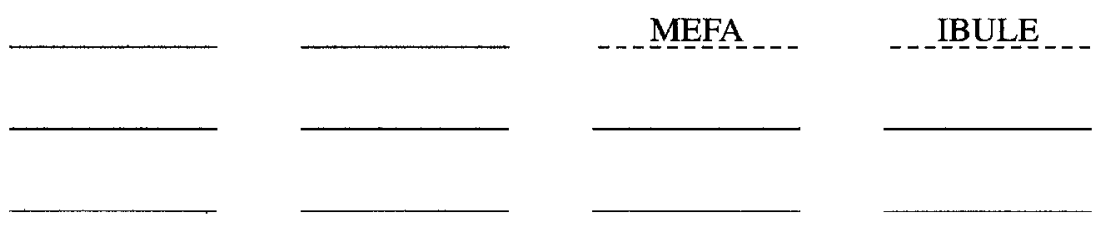

To this may be added the cultural fact that facial scarification used to serve as an identity card. It thus can help to trace the home address of a lost child since there are lineage scarifications. How do we translate for example the use of cowries and Opele ${ }^{4}$ in a scene of Ifa divination where the wishes of the gods are revealed through these cowries? What meaning do the Frenchmen give to a lady who kneels down for her husband? The fact that Sango plaits his hair are among the cultural semantics or symbols that the translator has to grapple with. All said and done, we can safely say that all systems of non-verbal communication are a product of the culture whose values they purvey. These are therefore necessary tools or keys for unravelling the experience of other civilisations.

For example, to be able to decipher, decode or translate the message or poetry of the bata drum, an uninitiated neophyte has to spend up to twelve years under the leadership of a poetic group orchestra of bata players. It is important to stress the fact that this initiation into the knotty language of the bata drum begins at the tender age of six up to the age of twenty-four and sometimes beyond. And it is not even everybody that can have access to this education in the Yoruba society. Drummer families of repute, not desiring any competition whatever, keep jealously their repertoires which they hand down to their children as their heritage. Therefore to talk of translating into French the performances of bata drums is an arduous task. Bata drums cannot easily play French partitions, even if the translator can create some, because of the fundamental differences between Yoruba poetry and French poetry, Yoruba language being a tonal language.

It is this problem that leads us to the untranslatability of Yoruba songs, or poetry as Val Olayemi rightly remarked above. This is so because of the fact that French harmony or melody is different from Yoruba harmony or melody. Such hack translations deprive the French of the musicality of the original Yoruba sung version.

Let us quote a convincing example. In the forest scene, where Bisi is following the handsome man who breaks into a song:

Vendeuse de la purée d' igname, retournez, retournez vite.

The Choir choruses with him: Ninikunni.

The first part is well translated into French, but one cannot compose any music which keeps the musicality of the Yoruba version. This contradiction becomes so apparent to the 
extent that the French version cannot find any translation for the refrain: "Ninikunni". This was one of the problems we had when adapting the French version for NTA Channel 10 on the 7 th of October, 1983.

Our performance of the play on television in French was hampered and the futility of translating an opera into another language dawned in on us all.

To this may be added the esoteric language of the spirits, imps, etc. In the second scene "The Nocturnal Imps", Lanke, in spite of his Yoruba origin, cannot understand the language of the King of the imps - Oluugbo.

When he, Oluugbo, speaks in the esoteric language: "e e e ye ye ye ya ya" means: "Qui êtes-vous" ("Who are you?"). It is significant to note here that the author of this adaptation has created the character of the interpreter to highlight the fact that translation and interpretation have always been with, humanity since creation, and that to reduce misunderstanding to the barest minimum, humanity needs this ancient character. We know that more often than not misunderstanding leads to war and wars lead to untold suffering of the people. Therein lies the humanistic role of helping the reader of Omuti to understand the author in the same way the above interpreter has helped Lanke to comprehend the message of the Oluugbo, thereby reducing the risk of enmity between the two unfamiliar characters.

Assuming that the songs, the esoteric language of the spirits are part of the cultural inheritance of the Yorubas, an inheritance which is born with centuries of "doing", "of acting", of "behaving", French language as the target language has no equivalent because of the French different ways of doing, acting and behaving. This is not to say that there are no imps, fairies and ghosts in French or European literature. All European countries certainly have their Alice in Wonderland à la Lewis Carroll. This statement underlines the fact that there is communicability between the Yoruba people and the French in spite of the difficulties in establishing French equivalents of certain Yoruba phenomena, which are not necessarily known to the French. Suffice it to say that there is a shared belief in fairies and daemons among the French and the Yorubas.

That notwithstanding certain Yoruba lexical items which belong to the tropical climate remain untranslatable. In the second scene we translated "Asa" as "Faucon-Asa". The question that readily comes to mind is: why not "Faucon" for simple? To those not initiated into the magical importance of incantatory poetry to the Yoruba the answer is simple. But those who are versed in the magical significance of names in Yoruba, the inclusion of the noun Asa with the French rendering is only cultural. This is because the whole stanza represents Yoruba incantatory poetry. Since the expected effect can only be realised by the repetition of the magic word Asa, the word Asa has to be pronounced even in the French version, because it is the live-wire or the key-word. This same explanation goes for such musical word like Ajiringido, and the birds Abodesan, Ogbe, Aluko and many other fauna.

As for the tropical flora, the same cultural explanation, that is, their magical power and their medicinal properties or attributes are responsible for retaining them alongside their French translations. This explains why "Afe-tree", "Atare-pepper" were translated as "arbre-Afe" and "poivre-Atare". We did not translate "Eba" because of its cultural importance, but we translated "Iyan" as "purée d'igname". Why have we chosen this tactic? We did that just to make readers or spectators who are not Yorubas have a taste of Yoruba word sounds. Eba is made from gari or cassava flour. People of African descent or extraction in the French Caribbean for example can easily trace their roots if only they study metropolitan African staple foodstuffs. So can those of the English-speaking Tobago, Trinidad, Antigua, Dominican, etc. Thus our French translation of Omuti is an open window into Yoruba worldview. 
Certain words have peculiar cultural meanings and values. It is such cultural considerations that made us translate "Father" with the word pere in French in spite of the meanings the French may read into it. In the scene in question, that is, Scene Six the "Cruel King", Bisi uses the word "father" for Lanke, her husband. Our translation is deep-rooted in the culture of the Yoruba people. The French reader may want to know why a wife addresses her husband with the title "father". The explanation is simple. In Africa of bygone days, marriages were oftentimes contracted between two old Lords in order to cement bonds of friendship.

In such cases, a girl of sixteen used to be given in marriage to an old man of say fifty years or above. The logical relationship that thus exists between the bride and the bridegroom is that existing between a father and a daughter. This age gap makes the new bride show her husband the respect which is his due in the Yoruba cultural context. Hence the use of the word "father" or "père" which such a girl uses for her elderly husband. The respect for elders is therefore one of the contributions of the Yoruba to universal civilization. Like the French the Yoruba "vouvoie" an elderly person with the word "Eyin", "awon", etc. as a sign of reverence.

A classical example of this cultural relevance of our translation of the word "père" is supplied by the story of the Yoruba princess and her husband, "Omowa ati Okore", as preserved by Dele Ojo in his universally acclaimed record of the same title. The source of this story is the Yoruba oral tradition. The infamous princess called her husband friend instead of father. The husband frightened her to submission in the wilderness by metamorphosing into fire that encircled her and forced her to sing her song of lament:

$O$ Père! $O$ Père.

The hunter thus succeeded through magic to demonstrate his superiority over his wife. This is the type of cultural precision that this translation has taken into consideration. The French reader or spectator must therefore read this translation carefully with an eye or an ear for such cultural details, if he wants to get into the spirit of Yoruba ways of life in which the work is immersed. Yoruba riddles and proverbs are such cultural details. In the first scene, Ayo, one of Lanke's friends, starts the Drinkard's Party with a riddle:

Qu'est-ce qu'il y a dans la mer qu'il n'y a pas sur la terre?

Everybody answers back:

Mais oui. Mais oui.

Ce sont la lune et les étoiles.

Lanke poses his puzzle thus:

Il y a un grand rocher dans une rivière

Qui se plaint d'avoir soif!

Lanke says:

La réponse à ma devinette est

La langue dans la bouche.

The problem here is not one of vocabulary. It is that of a sound knowledge of Yoruba oral tradition. Only Yoruba who are versed in their cultural patrimonies can easily find answers to these puzzles. The rock and river are known by the French but the meaning by association to give to these things, the French cannot know. 
In the Yoruba country, riddles represent the spiritual training of young people. It is the medium through which the child's mental and intellectual agility is being sharpened.

Proverbs on the other hand are almost the exclusive preserve of elderly folks. Proverbs, like riddles, demand a deep knowledge of Yoruba speech patterns or utterances, their flora and fauna as well as their linguistic particularities. When there is no more palm wine to drink and a man offers a gourd of water to Dada, one of Lanke's friend, he retorts:

Quand on présente la tête des ignames aux invités c'est une autre manière de leur dire: Qu'il est grand temps qu'ils partent.

The meaning of this proverb is simple. It simply means: To give water to a guest is an affront, another way of treating him as they do gluttons. For yam heads are not good for eating. They are bitter. To give the bitter part of yams to a guest is nothing short of an insult. Proverbs by their very nature as syncopated stylised language demand a lot from all translators.

The conclusion one can draw from this study is that there is communicability in spite of some cases of untranslatability which one can mark out here and there in the French translation of Omuti. It is this communicability which spurred us on to even begin the study.

Many are those who will follow up with patience the trudging along of the drunkard in the bush of fairies and imps; in this bush of the living and the dead; in this universal quest for a better future which he dreams about. After all, it is from dreams that most realities that we experience today are born. The existence of the supernatural and the real in this incredible play responds therefore to nature itself; at times strikingly real and at others intangible and elusive.

\subsection{Literary Translations, Publishers, African Universities and Critics}

B.W. Andrezejewski (1965: 95), in his article "Emotional Bias in the Translation and Presentation of African Oral Art" writes:

So far, however, the oral cultures of Africa are little known in the world outside, and have made as yet hardly any contribution to a better understanding of man in his African aspect.

African sculpture, music and dancing have made their impact outside Africa, but they are in this respect much more fortunate than oral art: they appeal directly to the eye and the ear and need no one to translate them.

The import of B.W. Andrezejewski, point of view to the development of literary translation in Africa resides in the fact that it hits the nail on the head. That is to say that African humanism has not yet been truly documented for the consumption of biased extra-African peoples or rather to confirm the universality of human values and the essential sameness of human nature. According to him:

The reason why the artistic worth of African oral art has not yet met with the appreciation it deserves lies (...) in the dearth of good translation and insufficient research.

It is true that publishers the world over will publish what they can sell, because they see publishing essentially as a business venture where they have to maximize their profit. Most of them, at least in Africa, if not in Europe and in America, will only publish official set books (school texts) that they can sell by the hundreds of thousands if not a million copies. 
This situation condemns obscure and unsung African writers to the cultural ghetto to which they belong for lack of patronage, at home and abroad. Therein lies the importance of all the Curriculum Development Institutes of Africa. Examination Councils like the West African Examination Council, those of East Africa, French-speaking Baccalauréat bodies should encourage the teaching of books listed in Appendices I-V. This way African publishing houses and foreign publishers will be encouraged to publish African works in translation. Such an official consecration is badly needed now. After all, the 1963 Sierra Leone resolution adjudged African literary works as worthy of being taught in our schools and universities. It is only necessary that, over two decades after, African States should execute this important cultural resolution. It is gratifying to say that there are now many publishing houses on the soil of Africa as shown in the Appendices. This new development will only augur well for the publication of African translated works. For reasons that are not unconnected with emotional bias against African cultures, a bias which in the words of Andrezejewski insidiously pervades the way of thinking in Europe, America, Asia, it is not unlikely for European publishing houses to reject African manuscripts. This prejudice dies hard and does affect the dissemination of African world view. Wole Soyinka, who translated Ogboju Ode ninu Igbo Irun Male into English with the title The Forest of a Thousand Daemons once revealed in his work Myth, Literature and the African World how certain key individuals at Cambridge University did not believe in a "mythical beast" known as African literature.

Andrezejewski (1963: 95) attested to this when he wrote:

In conversation with otherwise well-educated people one may be asked questions like can Africans have literature if some of their languages are still unwritten or if they have very little Printed materials? If one replies that oral art is a type of literature and refers to examples from old English, Ancient Greek, Icelandic or Provençal literatures, the reaction is at best scepticism, at worst horror, as if the comparisons were somehow blasphemous.

These are some of the reasons why our publishing houses and our governments should work hand in hand in projecting our cultures abroad. The governments should not put printing materials under licence and the African publishers should encourage translations of African literary works. All the translations in Appendices I and II are yet to be published. Profitability and cash nexus will certainly affect the dissemination of our literary patrimonies. In spite of the efforts of the publishers of Wole Soyinka's English version of D.O. Fagunwa's work at mounting a grandiose publicity campaign for Wale Ogunyemi's Langbodo, a play inspired by the former's translation that is by launching the said play in Ondo, Ogun, Oyo, Lagos, Kwara States, i.e., the Yoruba-speaking States of Nigeria, they did not include the work among sets books to be studied in these hitherto free education and free book states. How then does one expect such publishers to invest their resources in publishing a French version of an unsung author, but not an unknown author to the numerous popular theatre-goers of the theatre belt of Africa, Western States of Nigeria? These are some of the factors that hinder the dissemination of African literary patrimony and prevent Africa from taking its rightful place among the literatures of the world. But our faculties of arts are to blame for this state of things. According to Andrezejewski (1965: 101):

If Greek literature can be studied in translation why cannot the same be done with African oral art? Experiments could also be made with extramural lectures and talks for the general public, and more could be done through such media as radio and television.

This is true of the High School Curricula and the Department of English, University of Lagos, where the course ENG 485, "Masterpieces of European Literature", is taught to African students. Brecht, Dante, Sophocles, Cervantes, Molière, Baudelaire, 
Tolstoy, Dostoevsky, Ibsen, Goethe, Homer, Mann, Kafka, Grass, etc., are also taught in translation. One then wonders why Soyinka's English version of D.O. Fagunwa should not be included in the corpus of English Departments of African Universities; and why J.O. Abioye's Yoruba translation of le Mandat and Waiting for Godot and Dr. S.O. Esan's translations of Greek classics into Yoruba as presented in Appendix I should not be taught in the Department of African Languages and Literatures. In the same vein, Dr. Jide Timothy-Asobele and Dr. J.O. Abioye's translation of Yoruba operas and novels into French should be studied in Departments of French of African Universities.

Students or candidates for Baccalaureat, etc., should be encouraged to read these French versions for their "O" and "A" Level French examinations. The merit of such translations for a section of Nigerian students will be the religious fact that they reflect Nigerian cultural realities, a fact that will facilitate their second language acquisition and for the non-Nigerian students, a rewarding voyage towards relishing the Nigerian ways of life and world view. After all, Senghor's poems, Oyono's works, Mongo Beti, Sembene Ousmane, etc., are not set books for Nigerian students writing literature in English Examinations at all levels, that is, at " $\mathrm{O}$ " and " $\mathrm{A}$ " Levels and in all Nigerian institutions of higher learning.

It is gratifying to note that some of the above works are meticulously annotated by the translators. This is because of the fact that an African work translated into any language without appropriate introduction or annotations may seem very strange or even incomprehensible in English and French. This is why in God's Bits of Woods by Sembene Ousmane, such Wolof expressions as "M'ba", "Djenne", "ba", "bassi", "Bakayoko", etc., needed to be translated in the glossary or with footnotes.

Andrezejewski (1965: 99) was right when he wrote:

No less insidious are translations in which, without any warning to the reader, all the unfamiliar cultural elements of the original are suppressed, and a style is employed which is hardly at all related to the original.

This problem raises the question of the objective criteria for evaluating literary translations. In other words, how does one say this in the best translation of such and such a literary text? We are already in the domain of literary criticism or the role of critic in the development of literary translations.

We are aware of the fact that some African works translated into French and English are now being considered for the best literary translation prizes by the Nigerian Association of Translators and Interpreters (NATI).

The question that readily comes to mind is this: What criteria will the jury use in arriving at its decision on any particular book? Are there other translations of the same book? These questions are pertinent in the light of the conclusion that Val Olayemi (1968: 33) drew:

When that depression common to all translators sets in, he should draw consolation from the fact that the best of translations are but imperfect reproductions, for there can be no final translation of truly great poets.

This is not to say that Val Olayemi condemns translations. For Samuel Ade-Ojo (1985: 3) writes:

However, a bad translation of a text is still better than the absence of translation of the text since the unilingual reader or the reader ignorant in the language of the ST (source text) would have been deprived access to the text (...) This does not, however, imply that we want to praise incompetent translators or shower accolades on defective, that is, misconstrued, inadequate and superficial translations. 
What then are the qualities of a good translator of literary works? According to Andrezejewski (1965: 100):

Future translators must have a combination of two qualities: linguistic competence and literary talent. Unless a translator knows well the language from which he translates and has a literary gift in the language into which he translates, the end product of his endeavours will be either inaccurate or uninspired, or both.

It is true that if the translator's mother tongue is not an African language, his task will be a difficult one. J.O. Abioye (1985) attested to this when he, a Yoruba, translating a Yoruba writer, D.O. Fagunwa, into French, wrote:

To those who understand the Yoruba language very well and have read or studied some or all of Fagunwa's novels, one thing is clear: Fagunwa is difficult and clumsy to translate into any other language.

The above quotations have highlighted the problem of translation generally and that of literary prizes in particular, for how can one single out one book or one translator for honour while there are Lusophone, Hispanophone, Anglophone, etc., African works in translation? This writer has written elsewhere (Jide Timothy-Asobele 1982: 52-53) welcoming the cancellation of literary prizes during the 1977 Festac 77 of Lagos, Nigeria. This is because of the in-fighting that is rife in literary circles of Africa, in-fightings that disunite Africa instead of uniting it. We suggest, therefore, that our critics should find many avenues for projecting translated literary works of Africa (see Appendix V). They can use the various media at their disposal, that is the radio, TV, newspapers, literary journals, films, specialized or occasional publications, etc., to project this notion of dialogue of cultures. Bilingual literary journals like NSAL, Présence africaine, Abbia, Eureka, etc., are alive to their role in this particular respect. Reviews of translated African literary works should be encouraged on the pages of African newspapers. This way, the African literary patrimonies will be effectively covered and projected for world consumption. That is the avowed oath of African literary translators.

The Nigerian government must be emulated in this respect: for publishing in English two books on Festac 77 literary writers from Africa and the diaspora: Black and African Writing: A Festac Anthology and Seventeen Black and African Writers on African Writing, edited by Theo Vincent. These two books are unique in the sense that works of Anglophone, Francophone, writers, etc., appeared in one single volume, while the second book was a tête à tête with all these African writers. A singular honour for readers to engage in dialogue with these master thinkers of our race.

In conclusion, the fact that the Yoruba adaptation of Amos Tutuola's Palm Wine Drinkard by Kola Ogunmola gave the book a new wash of popularity and made it undoubtedly accessible to a larger public (Alain Ricard 1972: 55), coupled with the fact that the medium of the Travelling theatre gave it added popularity - an allusion to the second theatrical prize awarded it in the Algiers 1969 Pan-African Cultural Festival, an award which shows that a local work could have its own way to celebrity. Duro Ladipo's and Hubert Ogundo's art have gone beyond the borders of Nigeria. Their works have received enthusiastic welcome at festivals in London, Paris, Lome, Cotonou, Accra, New York, London, Berlin, etc. French translations of their works will only confirm our abiding faith in African unity through cultural exchanges and communications. This matters over and above everything for the political, economic and mental development of Homo Africanus. It is our hope that international symposia, conferences, seminars, congresses on literary translations in Africa will be multiplied in the not too distant future to highlight the need for literary translations and translators, and willing publishers in Africa's 
march toward self-sufficiency in a continent where more than $85 \%$ of the cultural commodities, books included, are written and printed abroad, a situation that drains African States' meagre hard currency. Now is the time to start work for the cultural and intellectual growth of our continent.

\section{References}

1. "The translation presented some peculiar problems. The author for example uses English conjunctions (notably but and or) in an unusual way, which gave me a lot of headache. On the other hand, I had to resist the temptation of rationalising an account whose 'inconsequence' and 'contradictions' sometimes even slipped into the structure of the sentence."

2. "A palm-wine tapster is the man who taps palm-wine. I translated this expression by 'Malafoutier', although this word was used in the Congo and not in West Africa. 'Gris-gris' is for juju and 'Féticheur' for juju-man."

3. Bata drums are the favourite drums of the Yoruba God of War, Ogun.

4. Opele is part of the paraphernalia of Ifa divination among the Yorubas.

\section{BIBLIOGRAPHY}

ABIOYE, J.O. (1985): "Translating Fagunwa into French: Need and Problems," paper presented at the 4th International Conference of the Nigerian Association of Translators and Interpreters (NATI), 24th-28th April, 1985, held at University of Benin, Nigeria.

ADE, S.O. (1985): "The Role of the Translator of African Written Literature in Inter-Cultural Consciousness and Relationship," paper presented at the International Conference of NATI, 24th-28th April, 1985, held at University of Benin, Nigeria.

ANDREZEJEWSKI, B.W. (1965): "Emotional Bias in the Translation and Presentation of African Oral Art," in African Language Review, 4, University of Sierra Leone.

ASIWAJU, I.A. (ed.) (1964): Partitioned Africans, Lagos, University of Lagos Press.

ECHERUO, M.J.C. (1981): "Concert and Theatre in Late 19th Century Lagos," in Yemi Ogunbiyi (ed.), Drama and Theatre in Nigeria: A Critical Source Book, Bath, The Pitman Press.

OLAYEMI, Val (1968): "Substance and Circumstance: Note on Translating Yoruba Poetry," in African Notes, 4:3, Institute of African Studies, University of Ibadan, Nigeria.

QUENEAU, Raymond (1953): l'lvrogne dans la brousse, Paris, Gallimard. Original by Amos Tutuola, The Palmwine Drinkard, London, Faber and Faber, 1952.

RICARD, A. (1972): Translated by Osofisan (1983): Theatre and Nationalism: Wole Soyinka and Le Roi Jones, Ife, University of Ife Press. Théâtre et nationalisme :Wole Soyinka et le Roi Jones, Paris, P.A., 1972.

TIMOTHY-ASOBELE, Jide (1982): “African Masterpiece: What Criteria?," in Nigeria Magazine, 141.

TIMOTHY-ASOBELE, S.J. (1984): "The Preparation of Teachers of English, French and Yoruba for the School System," in Nigerian Language Teacher, 6: 1 .

\section{APPENDIX I: WORKS TRANSLATED INTO YORUBA}

PLATO: Crito - K'a soto k'a $k u, 1963,10 \mathrm{p}$.

PLAUTUS: Mercator - Orekelewa, 1965, $10 \mathrm{p}$.

SOPHOCLES: Oedipus Tyrannus - Teledalase, $1965,10 \mathrm{p}$.

VERGIL: Aeneid II Trojan Horse - Esin Atiroja, 1966, 20 p. Translated by Dr. S.O. Esan but not yet published. SEMBENE, Ousmane: le Mandat - Sowedowo, in press (New Horn), Paris, P.A., 1962, Ibdan.

BECKETT, Samuel: En attendant Godot - Exi maa ri ati sun Akan..., Paris, les Éditions de Minuit, 1952. These two works are translated by Dr. J.O. Abioye.

N.B.:

(i) Kalevala, a finish work is at present being considered for translation into Yoruba by a team of translators from the Department of African Languages and Literatures of the University of Lagos, Nigeria.

(ii) A Yoruba version of Shakespeare's Julius Caesar, Juliosi Sisa, was performed at the National Theatre, Iganmu, Lagos, in 1981.

(iii) Appendices I-IV do not in any way contain an exhaustive list of literary translations in Africa. 


\section{APPENDIX II: YORUBA WORKS TRANSLATED INTO FRENCH}

D.O. Fagunwa's work* Ogboju Ode ninu Igbo Irunmale, London, Nelson, 1948; les Odyssées du chasseur à coeur vaillant dans la forêt.

Igbo Olodumare, London, Nelson, 1949; la Forêt de l'omnipotent.

Ireke-Onibudo, London, Nelson, 1949; la Fortune sourit aux audacieux.

Irinkerindo Ninu Igbo Elegbeje, London, Nelson, 1954; les Parcours interminables dans la forêt d'Elegbeje.

Adiitu Olodumare, London, Nelson, 1961; les Mystères divins.

* The UNESCO has shown interest in publishing all the above titles translated by Dr. J.O. Abioye of the Department of Modern European Languages, University of Lagos.

Kola Ogunmola's Opera, The Palmwine Drinkard, (Omuti) Ibadan, Abiodun Printing Press, 1972; l'Ivrogne.

Duro Ladipo's Opera, Oba Koso, Ibadan, I.U.P., 1968; Oba Koso.

Duro Ladipo's Opera, Eda, Ibadan, I.U.P., 1970, Eda.

Wale Ogunyemi's Opera, Obaluaye, Ibadan, Caxton, 1972; Obaluaye.

Wale Ogunyemi's, Langbodo, Ikeja, Nelson, 1979; Langbodo.

These five works were translated by Dr. S.J. Timothy-Asobele. He has the copyright for the French translation of Omuti, Obakoso, Eda, etc.

N.B.

Mercantile, many philistine considerations have always influenced the attitudes of publishing houses to literary manuscripts that are not on WASC, and GCE or NSC programmes. Amos Tutuola was quoted as saying that his Yoruba version of the famous Palm-wine Drinkard has not yet received any favourable reply from publishing houses.

\section{APPENDIX III: SOME YORUBA WORKS TRANSLATED INTO ENGLISH}

D.O. Fagunwa's Ogboju Ode ninu Igbo Irunmale, London, Nelson, 1948; Wole Soyinka: The Forest of a Thousand Daemons, Lagos, 1968.

Kola Ogunmola's Omuti, The Palmwine Drinkard, Ibadan, Abiodun Press, 1972; translated by R.G. Armstrong R.L. Awujoola and Val Olayemi.

Duro Ladipo's Obakuso, Oba Koso, Ibadan, I.U.P., 1968, translated by R.G. Armstrong, R.L. Awujoola and Val Olayemi.

Duro Ladipo's Eda, Ibadan, I.U.P., 1970, translated by Val Olayemi.

Wale Ogunyemi's Obaluaye, Obaluaye, Ibadan, Caxton, 1972, translated by the author.

N.B.

To this section can be included creative critical works on Yoruba oral poetry, written by such Ijala and Ifa poetry exponents as Profs. Babalola and Abimbola.

S.A. Babalola's The Content and Form of Yoruha, Jjala, London, O.U.P., 1966.

W. Abimbola's Sixteen Great Poems of Ifa, Paris, UNESCO, 1975.

Fela Sowande's Ifa, Yaba, Forward Press, 1964.

\section{APPENDIX IV: FRENCH-SPEAKING AFRICAN WRITERS TRANSLATED INTO ENGLISH}

Mongo Beti: Mission terminée, Paris, Butchet-Chastel, 1957; Peter Green: Mission to Kala, London, Heinemann, 1964.

Mongo Beti: le Roi miraculé, Paris, Butchet-Chastel, 1958; Peter Green: King Lazarus, London, Muller, 1969.

Mongo Beti: le Pauvre Christ de Bomba, Paris, Lafont, 1956; Gerald Moore: The Poor Christ of Bomba, London, Heinemann, 1971.

Mongo Beti: Remember Ruben, Paris, UGE, 1974; Remember Ruben, Ibadan, Heinemann, 1979.

Mongo Beti: Perpétue et l'habitude du malheur, Paris, Butchet-Chastel, 1974; Perpetua and the Habit of Unhappiness, Ibadan, Heinemann, 1974.

Ferdinand Oyo: Une vie de boy, Paris, Julliard, 1956; John Reed: House Boy, Ibadan, Heinemann, 1984.

Ferdinand Oyono: le Vieux nègre et la médaille, Paris, Julliard, 1956; The Old Man and the Medal, London, Heinemann, 1967

Francis Bebey: la Poupée ashanti, Yaoundé, CLE, 1973; The Ashanti Doll, Ibadan, Heinemann, 1975.

Francis Bebey: le Fils d'Agathe Moudio, Yaoundé, CLE, 1967; Agatha Moudio's Son, Ibadan, Heinemann, 1971. 
Sembène Ousmane: les Bouts de bois de Dieu, Paris, Presses Pocket, 1960; Francis Price: God's Bits of Woods, London, Heinemann, 1962.

Le Mandat, Paris, Présence africaine (P.A.), 1962; Clive Wake: The Money Order, London, Heinemann, 1971.

Xala, Paris, P.A., 1973; Clive Wake: Xala, Ibadan, Heinemann, 1976.

L.S. Senghor: Nocturnes, poèmes, Paris, Seuil, 1961; J. Reed: Nocturnes: Love Poems, London, Heinemann, 1969.

Malick Fall: la Plaie, Paris, Michel, 1967; The Wound, London, Heinemann, 1967.

Mariama Ba: Une si longue lettre, Dakar, NEA, 1981; So Long a Letter, Ibadan, Heinemann, 1982.

David Diop: Coups de pilon, Paris, P.A., 1956; Hammer Blows, Ibadan, Heinemann, 1974.

Cheik Hamidou Kane: Aventure ambiguë, Paris, Julliard, 1961; K. Woods: Ambiguous Adventure, New York, Walker, 1963.

Birago Diop: les Contes d'Amadou-Koumba, Paris, P.A., 1961; D. Blair: Tales of Amadou-Koumba, London, O.U.P., 1966.

Camara Laye: l'Enfant noir, Paris, Plon, 1953; James Kirkup: The African Child, London, Collins, 1959.

Le Regard du roi, Paris, Plon, 1954; James Kirkup: The Radiance of the King, London, Fontana, 1965.

Dramouss, Paris, PIon, 1966; James Kirkup: A Dream of Africa, Glasgow, Collins, 1980.

Maitre de la parole, Paris, Plon, 1978; The Guardian of the Word, Glasgow, Fontana, 1980.

Seydou Badian: la Mort de Chaka, Paris, P.A., 1961; Clive Wake: The Death of Chaka, Nairobi, O.U.P., 1968.

Yambo Ouologuem: le Devoir de violence, Paris, Seuil, 1968; Ralph Maheim: Bound to Violence, London, Heinemann, 1971.

Bernard B. Dadié: Climbié, Paris, Seghers, 1956; Climbié, London, Heinemann, 1971.

Tchicaya U'Tam'si: A triche-coeur, Paris, P.J. Oswald, 1960; Gerald Moore: Selected Poems, London, Heinemann, 1970.

Epitomé, Paris, P.J. Oswald, 1962.

Le Ventre, Paris, P.J. Oswald, 1964.

Arc musical, Paris, P.J. Oswald, 1970.

Djibril Tamsir, Niane: Soundjata, ou épopée mandingue, Paris, P.A., 1960; G.D. Pickett: Sundiata: An Epic of Old Mali, London, Longman, 1965.

Guillaume Oyono-Mbia: Trois prétendants... un mari, Yaoundé, CLE, 1964; Three Suitors, One Husband, London, Methuen, 1968.

Guillaume Oyono-Mbia: Jusqu'à nouvel avis, Yaoundé, CLE, 1970; Until Further Notice, London, Methuen, 1968.

\section{APPENDIX V: ENGLISH-SPEAKING AFRICAN WRITERS TRANSLATED INTO FRENCH}

Wole Soyinka: The Interpreters, Ibadan, Heinemann, 1965; G. Landré: les Interprètes, Paris, P.A., 1979.

Wole Soyinka: The Lion and the Jewel, London, O.U.P., 1963; J. Chuto's P. Laburthe-Tobra: le Lion et la perle, Yaoundé, 1968.

Wole Soyinka: A Dance of the Forest, London, O.U.P., 1965; E. Janvier: la Danse de la forêt, Honfleur, P.J. Oswald, 1971.

Wole Soyinka: The Swamp Dwellers, London, O.U.P., 1965; E. Janvier: les Gens de Marais, Honfleur, P.J. Oswald, 1971.

The Strong Breed, London, O.U.P., 1965; E. Janvier: Un sang fort.

The Trials of Brother Jero, London, O.U.P., 1965; E. Janvier: les Tribulations du frère Jero, Honfleur, P.J. Oswald, 1971.

Chinua Achebe: Things Fall Apart, Ibadan, Heinemann, 1958; M. Vigny: le Monde s' effondre, Paris, P.A., 1966.

No Longer at Ease, Ibadan, Heinemann, 1960; J.R. Duclos: le Malaise, Paris, P.A., 1974.

Arrow of God, Ibadan, Heinemann, 1964; I.A. d'Almeida and Olga Simpson: la Flèche de dieu, Paris, P.A., 1978.

A Man of the People, Ibadan, Heinemann, 1966; A. Diop: le Démagogue, Dakar, NEA, 1977.

Girls at War, Ibadan, Heinemann, 1972; J. de Grandsaigne: Femmes en guerre, Paris, Hatier, 1981.

Cyprian Ekwensi: Burning Grass, Ibadan, Heinemann, 1968; F. Balogun: Feu ardent, Paris, P.A., 1978.

Cyprian Ekwensi: Lokotoun and Other Stories, London, Bolt-Walton, 1965; J. de Grandsaigne, G. Spackey: la Danseuse d'Ivoire, Paris, Hatier, 1982.

Nkem Nwanko: My Mercedes Is Bigger than Yours, Ibadan, Heinemann, 1975; Josette Mane: Ma Mercedes est plus grosse que la tienne, Paris, Hatier, 1982.

Amos Tutuola: The Palmwine Drinkard, London, Faber and Faber, 1952; R. Queneau: l'lvrogne dans la brousse, Paris, Gallimard, 1953.

Femi Osofisan: The Chattering and the Song, Ibadan; Nicole Medjigbodo: la Trame et la chaine, Paries, Peuples noirs, 1980.

Ayi Kwei Armah: The Beautiful Ones Are Not Yet Born, Ibadan, Heinemann, 1968; l'Age d'or n'est pas pour demain, Paris, P.A., 1978.

Ngugi Wa Thiongo: A Grain of Wheat, Ibadan, Heinemann, 1964; Et le blé jaillira, Paris, P.A., 1978. 
APPENDIX VI: LITERARY CRITICISM: WORKS IN FRENCH AND IN ENGLISH WRITTEN BY AFRICANS TO FOSTER DIALOGUE OF CULTURES

S.O. Mezu: The Poetry of Senghor, London, Heinemann, 1973; Leopold Sedar Senghor et la défense et illustration de la civilisation noire, Paris, Dadier, 1968.

Bakari Traoré: le Théâtre négro-africain et ses fonctions sociales, Paris, P.A., 1958; Dapo Adelugba: The Black African Theatre and Its Social Functions, Ibadan, I.U.P., 1972.

Alain Ricard: Théâtre et nationalisme: Wole Soyinka et le Roi Jones, P.A., 1972; Femi Osofisan: Theatre and Nationalism: Wole Soyinka and Le Roi Jones, Ife, I.U.P., 1983.

Abiola Irele: Lectures africaines: A Prose Anthology of African Writing in French, London, Heinemann, 1969.

Clive Wake: An Anthology of African and Malagasy Poetry in French, London, O.U.P., 1965.

Clive Wake: French African Verse with English Translation, London, Heinemann, 1972.

A.C. Brench: Writing in French from Senegal to Cameroon, London, O.U.P., 1969.

Thomas Melone: Chinua Achebe et la tragédie de l' histoire, Paris, P.A., 1973. 